\title{
Enforcement of Labor Regulation and Firm Size
}

\author{
Rita Almeida* \\ World Bank \\ Pedro Carneiro \\ University College London, Institute for Fiscal Studies \\ and Centre for Microdata Methods and Practice
}

May 8, 2008

\begin{abstract}
This paper investigates how enforcement of labor regulation affects firm size and other firm characteristics in Brazil. We explore firm level data on employment, capital, and output, city level data for economic city characteristics and new administrative data measuring enforcement of regulation at the city level. Since enforcement may be endogenous, we instrument this variable with the distance between the city where the firm is located and surrounding enforcement offices, while controlling for a very rich set of city characteristics (such as past levels of informality in the city). We present suggestive evidence of the validity of this instrument. We find that stricter enforcement of labor regulation constrains firm size, and leads to higher unemployment.
\end{abstract}

Keywords: Enforcement of Labor Regulations, Labor Demand, Employment, Productivity.

JEL Classification codes: H00, H10, J50,K20, L50, L60, O17,O40.

\footnotetext{
*Corresponding author: Rita Almeida (ralmeida@worldbank.org). We thank the Brazilian Ministry of Labor for providing the data on enforcement of labor regulation and important information about the process of enforcement, especially Edgar Brandao, Sandra Brandao and Marcelo Campos. Renata Narita provided excellent research assistance. We thank Daron Acemoglu, Loren Brandt, Robin Burgess, George Clarke, Flavio Cunha, Esther Duflo, Saul Estrin, Ana Fernandes, Mary Hallward-Driemeier, Gary Fields, John Haltiwanger, Jennifer Hunt, Adriana Kugler, Sara Lemos, Norman Loyaza, David McKenzie, Joao Cesar das Neves, Stefano Scarpetta, Luis Serven, Rodrigo Soares, Kathy Terrel, Eric Verhoogen, and especially the editor, Simeon Djankov, and two anonymous referees, for valuable suggestions. We also received excellent comments from participants in EALE 2005 meetings, IZA conference on Transition Economies (Bologna) Microeconomics Development Network Meeting (Beijing), seminars at the World Bank and Universidade Catolica Portuguesa, 2006 SOLE Meetings, and 2006 IZA/World Bank Conference on Employment and Development. Carneiro gratefully acknowledges the financial support from the Economic and Social Research Council for the ESRC Centre for Microdata Methods and Practice (grant reference RES-589-28-0001), from ESRC grant RES-000-22-2805, and the hospitality of Georgetown University, and the Poverty Unit of the World Bank Research Group. This paper benefited from financial support from a grant from the World Bank.
} 


\section{Introduction}

In most developing countries, strict labor market regulations imply high costs of employing workers and low labor flexibility. These regulations together with an imperfect and costly monitoring in developing countries create a strong incentive for these firms to overcome regulation and evade the law. However, firms differ in their evaluation of the benefits and costs of evading regulations. While some firms comply with all regulations imposed in the law, others choose to avoid some dimensions such payroll taxes or health and safety rules. Another group of employers choose to avoid regulation altogether by hiring in the informal labor market. Our paper quantifies the effects of enforcement on firm size and on other firm outcomes, by exploring the fact that labor regulation is not enforced uniformly within a country. We will explore data from Brazil, a very large country where enforcement of labor regulation is highly decentralized, varying widely across locations. To our knowledge, this type of variation has not been used before to quantify the effects of labor regulation. ${ }^{1}$

In particular, we analyze how changes in enforcement affect firm size, output, and productivity. We argue that the main channel through which stricter enforcement will affect labor markets is by increasing labor costs. Cardoso and Lage (2007) argue that in Brazil, most of the labor inspections are focused on large and formal firms. ${ }^{2}$ Moreover, they suggest that much of enforcement is related with compliance with mandatory severance payments (FGTS) and with health and safety regulations, and some formalization of work contracts.

We measure enforcement using a novel and unusual administrative dataset containing the

\footnotetext{
${ }^{1}$ However, a recent study by Caballero, Cowan, Engel and Micco (2006) argues that labor regulation has weaker effects in countries where enforcement is weak. Apart from this, papers in this literature do not look directly at enforcement. As for outcomes, many papers quantify the efficiency costs of strict regulation for labor outcomes such as employment, unemployment and wages (Freeman, 1988, Lazear, 1990, Elmeskov, Martin and Scarpetta, 1998, Blanchard and Wolfers, 2000, Nickell, 1997, Nickell and Layard, 2000). Although less studied labor regulations will also affect the firm's demand for labor as well as the firm's investment strategies and productivity (Holmes, 1998, Besley and Burgess, 2004, Autor, Kerr and Kugler, 2007).

${ }^{2}$ The reasoning for this is based on three facts. First, and most important, informal firms are not formally registered and may be hard to find. Second, labor inspectors have a performance based pay scheme, which gives them an incentive to penalize infractions, especially in large firms. In particular, up to $45 \%$ of their wage is tied to the efficiency of the overall enforcement system $(1 / 3$ is tied to the inspectors own performance while $2 / 3$ 's is tied to the system's global performance). Third, fomal firms tend to be have more organized administrative records. This makes the inspection activity easier and more effcicient (i.e., obtain a higher number of fines per hour of inspection).
} 
number of firms inspected by labor inspectors in a given city (municipio) in 2002. There are two reasons why enforcement may constrain firm size. First, labor regulation causes labor costs to be higher (because firms need to comply with payroll taxes, health regulations, and use of formal workers which are much more costly than informal workers). This leads firms to hire less labor and possibly to scale down production. Second, larger formal firms are inspected more often because they are more visible. Therefore, keeping firm size small may help avoid detection of noncompliance. These constraints on size can be very detrimental for the economy because they restrict firm growth.

Unfortunately, we cannot assume that all variation in our measure of enforcement (which is measured at the city level) is exogenous. Some cities could have higher enforcement simply because they have a higher level of evasion (reverse causality); or because they are more developed, and (due to a better institutional environment) economic performance could be positively correlated with enforcement and negatively correlated with evasion of regulation (omitted variables). In order to address these problems, in our empirical work we instrument enforcement with a measure of its cost: the distance (measured in hours of travel) between the city where the firm is located and the nearest city (in the state) with a local office of the ministry of labour, which in Brazil is called the subdelegacia. Enforcement of labor regulation in Brazil is decentralized at the level of this subdelegacia, and each subdelegacia has the responsibility of maintaining compliance with the law in several surrounding cities. Labor inspectors usually travel by car.

Using this empirical strategy we estimate that a $1 \%$ increase in the number of inspections per hundred firms in the city leads to a $0.47 \%$ decline in the average employment of a firm, a $0.48 \%$ decline in output and a $0.46 \%$ decline in sales. We estimate that the impact of enforcement on output per employee and capital per employee is negative, but the estimates are not statistically significant. The reasoning behind our choice of instrument is that enforcement should be weaker where it is more costly, and the cost of enforcement depends on the distance to the enforcement office, which in this case is the subdelegacia. In our data, a 1 hour increase in the distance to a city with an office of the ministry of labor leads to a $24 \%$ decrease in inspections. 
We realize that our identification strategy may suffer from two problems, which we try to address. First, enforcement offices are not randomly assigned across Brazil, but they tend to be located in larger cities. Second, firms decide where to locate based on a variety of reasons, and firms wishing to avoid the labor costs associated with labor regulations more heavily may want to locate in areas where enforcement is weaker. In order to minimize these problems we control for several firm and city characteristics. At the firm level, we control for age of the firm, share of the firm that is state and foreign owned and, most importantly, industry dummies. The city level controls include population size in 1980, log output per capita in 1980, state fixed effects, and most importantly, distance to the state capital (measured in hours of travel), and two indices of institutional development in the city (access to justice and quality of public management). These variables are measured in 1980 because from the mid eighties and 90's onwards is the time we expect that local labor offices began exerting most of their influence on firms' behaviors. ${ }^{3}$ Therefore, our identification strategy is to compare different firms within the same state and industry, with similar characteristics in terms of age and ownership structure, located in cities of the same size and income per capita, with similar institutional development, which are equally far from the state capital, but which differ in their average distance to surrounding enforcement offices (we include additional controls in several of our specifications). Distance to the state capital is an important control meant to capture distance to large markets, or distance to cities with strong institutions, so that the variation we use to instrument enforcement is net of these effects, and captures essentially the enforcement cost.

We present several checks to our findings which suggest that our empirical strategy is valid. The magnitude of our estimates is very reasonable, and it is remarkably robust to the inclusion of several city characteristics which are good indicators of, for example, access to markets or other institutions, or institutional development of the city. Furthermore, when we look to firm characteristics such as age or type of ownership (public vs. private, foreign vs domestic), firms located near labor offices are not different from other firms. And, as we

\footnotetext{
${ }^{3}$ We chose to measure city level controls as early in time as we could (without losing too many observations), in an attempt to use predetermined variables. Contemporaneous measures of city characteristics may be endogenously affected by current enforcement.
} 
expect, most of the employment reduction we observe occurs for unskilled workers, and in the oldest firms (which are less likely to have chosen their location in response to changes in enforcement). It is unlikely that omitted variables are driving our results.

These results have important policy implications. First, labor regulation has a significant impact on firm size, measured by inputs or outputs. As argued in Rajan and Zingales (1998) and Kumar, Rajan and Zingales (1999), most of the observed growth is driven by growth of existing firms, not by the creation of new firms. Therefore, constraints to firm size can be highly detrimental to growth. Furthermore, effects on firm size may well translate into effects on employment, as long as the number of firms in a city does not rise sufficiently with enforcement to compensate for the reduced firm size. This is in line with the long literature on the effects of labor regulation on employment in developed and developing countries, which shows that labor regulation can be very costly in terms of efficiency. Second (related to the first), evasion of labor regulation by firms allows them to gain access to cheap and flexible labor. As emphasized by, for example, Acemoglu and Robinson (2006), social institutions are an equilibrium outcome, and trying to correct apparently dysfunctional institutions instead of what lies at their roots can sometimes lead to undesired results. In particular, widespread informal employment in Brazil may not only be a manifestation of high evasion and weak institutions, but also an equilibrium response to unreasonably stringent labor regulations. Compliance with the law can be more easily affected by changes in the law than by changes in enforcement. Furthermore, increasing enforcement without changing the law may lead to very rigid labor markets and poor economic performance. However, our paper does not imply that informal behaviors are necessarily desirable. Access to informal employment is helpful to circumvent strict labor regulation, but systematic violations of the law weaken the country's institutions and can hurt development in the long run. Therefore, if we thought regulation to be detrimental to firms, a possible recommendation for fostering growth in Brazil would be to promote more flexible labor laws, rather than advocating a more relaxed enforcement environment. ${ }^{4}$ Furthermore, in a labor market with frictions, stronger enforcement may

\footnotetext{
${ }^{4}$ See also Acemoglu (2001) for a model where labor regulation increases the number of "good jobs" provided in the economy.
} 
promote the formalization of the economy and an increase in the supply of "good jobs", as suggested in Acemoglu (2001).

Our paper contributes to and integrates insights from the literature on business regulations and their enforcement, labor regulations and labor informality. First, we relate to the literature studying the effects of legal rules and regulations, many of which related with legal origins, on economic outcomes (for a review see La Porta, Lopez-de-Silanes and Shleifer, 2007). This literature explores cross country and time series variation in several dimensions of regulations, including investor protection regulations, financial regulations, business entry and labor or tax regulations (e.g., Rajan and Zingales, 1998, Djankov, La Porta, Lopez-deSilanes, and Shleifer, 2002, 2003). Their findings strongly suggest that these regulations do affect resource allocation in the economy. Related work also explores cross country data to test the importance of contract enforcement on economic activity (e.g., Djankov, McLiesh, and Shleifer, 2007, Safavian, and Sharma, 2007). ${ }^{5}$

Second, we relate to the literature focusing specifically on the effects of labor market regulations on economic outcomes. Part of this literature explores cross country variation in the labor regulations (e.g., Botero, Djankov, La Porta, Lopez-de-Silanes and Shleifer, 2004, Nickell and Layard, 2000 and Heckman and Pages, 2003, Lazear, 1990, Blanchard and Wolfers, 2000, Blanchard and Portugal, 2001). These cross country studies suggest that stringent labor market regulations hamper economic efficiency. However, they pose identification and measurement problems that are difficult to overcome only with cross country data. This, together with the increasing availability of large micro data sets, has motivated a large literature exploring the changes in the labor regulations within specific countries. The major challenge here is that regulations are usually set at the national level (affecting all individuals similarly) and/or change very infrequently. ${ }^{6}$ In some cases, like the US or

\footnotetext{
${ }^{5}$ Safavian, and Sharma (2007) explore the same firm level data that we do for Brazil, but for 27 transition economies. They hypothesize that the effectiveness of creditor rights is strongly linked to the efficiency of contract enforcement. Their findings show that firms have more access to bank credit in countries with better creditor rights, but the association between creditor rights and bank credit is much weaker in countries with inefficient courts.

${ }^{6}$ Recently, several papers focus on specific changes in labor regulations that have occurred over time within countries (e.g., Barros and Corseuil, 2001) or in social security payments (e.g. Gruber, 1997, Kugler and Kugler, 2003).
} 
India, de facto regulations change across states of the same country (e.g., Holmes (1998), Autor, Kerr and Kugler, 2007, Besley and Burgess (2004), Ahmad and Pages, 2007, Amin, 2007). Holmes (1998) explores variation across US states and shows that those that enacted pro-business right-to-work laws had increases in manufacturing activity. Besley and Burgess (2004), Ahmad and Pages (2007) and Amin (2007) also find important effects of labor regulation on output, employment, investment and productivity in Indian manufacturing and services sectors. Autor, Kerr and Kugler (2007) use the adoption of wrongful discharge protections by US courts to estimate the impact of employment protection on productivity. They find that employment protection leads to reduced employment flows and lower productivity. Micco and Pages (2006) propose an alternative approach exploring variation in the de facto regulation across sectors and countries over time. They explore a differences-in-differences approach based on the hypothesis that labor regulations are more binding in sectors exposed to higher volatility in demand or supply shocks. Their findings show that stricter regulation slows down job turnover, and that this effect is larger for sectors that are intrinsically more volatile. In this paper we explore variation in the enforcement of labor regulation (rather than using variation in regulation itself) and we use firm level data (as in Autor, Kerr and Kugler, 2007, and instead of more aggregate data as in Besley and Burgess, 2004, Micco and Pages, 2006, or Boeri and Jimeno, 2005). This allows us to study the relationship between enforcement of labor regulation and alternative measures of measures firm performance.

Third, our work relates to the literature on informality. Direct and indirect tax rates as well as stringent labor regulations are usually found to be strong determinants of the size of the informal sector across countries (e.g., de Soto, 1989, Loayza, 1996, Schneider and Enste, 2000; see also de Paula and Scheinkman, 2006). However, enforcement of regulation and the quality of institutions are also important determinants of the way regulation affects informality (e.g., Johnson, Kaufmann and Zoido-Lobaton, 1998, Loayza, Oviedo and Serven, 2005). Some of the modern micro literature on informal labor markets (e.g., Maloney, 2004) suggests that we should look at the formal and informal sectors in an integrated way (as opposed to a segmented view of the labor market) and emphasizes the role of the informal sector as a source of unregulated labor to firms. This is the basis of the economic 
reasoning underlying our work, although our results are also consistent with some degree of segmentation in the labor market (e.g., Fields, 2004).

The paper is organized as follows. In section 2 we describe the Brazilian labor market, and section 3 describes the enforcement of regulation in Brazil, and the main data sets used. Section 4 briefly lays out the simple theory underlying our empirical work. In section 5 we present estimates of the link between enforcement of labor regulation and different indicators of firm outcomes using firm level data. Section 6 concludes.

\section{Enforcement of Labor Regulation}

Brazil is one of the countries in Latin America with stricter de facto labor regulations. Traditionally, much of the labor law is written in the country's constitution, which is very detailed and stipulates very specific legal provisions. ${ }^{7}$ This makes it very difficult to amend any of these provisions. The constitution of 1988 introduced several changes to the labor code (that had been in effect since the 40's), and most of these changes increased the degree of worker's protection.

In Brazil there are very favorable working conditions for workers with a formal work permit (carteira de trabalho, a document in which the employment history of the worker is registered). This permit officially entitles the worker to several wage and non-wage benefits paid for by the employer, such as retirement benefits, unemployment insurance, and severance payments. Worker benefits imply very high costs of employment for firms, which are well above the costs in other Latin American countries. In particular, the law establishes that workers can work at most 44 hours in a week, and that the maximum period for continuous shift work is 6 hours. The minimum overtime pay is set at 1.5 times the normal hourly wage. Employers are also obligated to offer paid leave to their employees, which is at least $4 / 3$ of normal wage, as well as a paid maternity period of 120 days. There also exists paternity leave, but it is smaller than maternity leave ( 5 days).

Even though it is not much more difficult to fire a worker in Brazil than in other Latin

\footnotetext{
${ }^{7}$ For a general description of the Brazilian labor regulation and its recent changes see Barros and Corseuil (2001)
} 
American countries, it is definitely much more costly. Employers must give prior notice of the dismissal to workers and, between this notice and the actual dismissal, workers are granted two hours a day to look for a job. This period is never smaller than one month and recently it became proportional to the worker's tenure. During this period, employers cannot adjust the employee's wage so this implies that $25 \%$ of her hours are paid but are not worked. In practice the productivity of a dismissed worker also falls once she is given notice of dismissal so that the overall decline to production is well above $25 \%$ (Paes de Barros and Corseuil, 2001, argue that in most of the cases the fall in production is closer to 100\%). Advance notice constitutes the bulk of dismissal costs in Brazil. Moreover, workers with non-justified dismissals have the right to receive a monetary compensation paid by the employer, beyond that accumulated in the worker's job security fund (FGTS). ${ }^{8}$ In particular, the law establishes that a penalty equal to $40 \%$ of the job security fund is to be paid to every dismissed worker without a just cause. The rate of accumulation of the fund is such that, for a tenure of 2.5 years on the job, this compensation reaches one monthly salary.

When evading the law, employers face the risk of being caught and having to pay a fine. The probability of being caught depends on the degree of enforcement in the region where the firm is located. It also varies with firm size, a proxy for firm visibility. Compliance with labor regulation in Brazil is enforced by the Ministry of Labor. Given the size of the country, enforcement is first decentralized at the state level ( the state level labor office is called delegacia or DRT ) and then at a more local level, the subregion (the local labor office is called subdelegacia). In each state, the delegacia is always located in the state capital and the number of subdelegacias within the state is a function of the size and of the economic importance of each region. For example, the state of Sao Paulo has 21 subdelegacias while other smaller states, like Acre or Amapa, only have one subdelegacia, which coincides with

\footnotetext{
${ }^{8}$ The Fundo de Garantia por Tempo de Servico (FGTS) is a government administered fund paid by the employers that is accumulated while the worker is employed by the firm. Each worker in the formal sector has his own account in the fund. The employer must contribute monthly with $8 \%$ of the employee's current wage to the fund. As a consequence the accumulated FGTS of a worker in a given firm is proportional to its tenure. Only workers who are dismissed for an unfair reason or those who retire have access to this fund. Upon dismissal, workers have access to the entire account, including all the funds accumulated in previous jobs, plus a penalty in proportion to the account accumulated in the firm from which they are being dismissed.
} 
the delegacia. Labor inspectors are affiliated with a particular subdelegacia and report to the head of the subdelegacia (subdelegado). They periodically visit firms within the region, assessing the compliance with several dimensions of labor law (e.g., payment of payroll taxes and severance payment, worker's formal registration, compliance with minimum wage regulation and hours of work). In theory, an inspection can be triggered either by a random firm audit, or by a report (often anonymous) of non-compliance with the law. In practice, since the number of labor inspectors is low relatively to the total number of reports, most inspections are triggered solely by reports of evasion. Reports can be made by workers, unions, the public prosecutor's office, or even the police.

There are different types of labor violations and all violations are punishable with fines. The main type of violations targeted by labor inspectors are the lack of payment of the job security fund, non-compliance with health and safety conditions on the job, and to a smaller extent, worker registration, at least if we assess it by the number of worker registrations. Nevertheless, looking at the number of worker registrations might not be the best measure if there is a deterrent effect of enforcement. Another important component of labor inspections consists of the fight against slavery and child labor.

Labor inspectors have a performance based pay scheme, which gives them an incentive to penalize infractions. In particular, up to $45 \%$ of their wage is tied to the efficiency of the overall enforcement system ( $1 / 3$ is tied to the inspectors own performance while $2 / 3$ 's is tied to the system's global performance). Their base salary is also good relatively to comparable alternatives. In 2004, labor inspectors had a monthly wage between USD 2,490 (starting position) and USD 3,289 (top management). Although these inspectors could still have an incentive to collect bribes, in practice, especially in the more recent years, this does not seem to be a very serious problem. However, we cannot rule out that there is some corruption in the system.

When faced with violations of the labor code, inspectors must immediately notify the firm. After the notification, the firm has 10 days to present evidence in its defense. After that period, the process is re-examined by a different inspector from the one that issued the fine, who deliberates about its fairness. This result is then reported to the head of the 
subdelegacia (subdelegado). If firms do not refute the claim and pay the fine within 10 days of their notification, there is a $50 \%$ discount on the amount of the fine. Alternatively, if firms decide to appeal the decision, they must deposit the total value of the penalty until a second decision has been reached. In practice, small and medium firms pay the fines early in the process to take advantage of the discount. Larger firms, with juridical departments, tend to refute the deliberations and, often, avoid the payment of fines altogether. The fines can be either fixed, or indexed to firm size and profitability. For example, a firm is fined by Reais 446 for each worker that is found unregistered during an inspection. Or, depending on its size and profitability, a firm can be fined by an amount between Reais 16 and Reais 160 per employee, if they do not comply with the mandatory contributions to the FGTS.

\section{Data}

\subsection{Enforcement of Labor Regulations}

The Ministry of Labor makes an effort to apply an homogeneous criteria in the enforcement of labor regulation throughout the country, but in practice this is very difficult to achieve. ${ }^{9}$ Enforcement is not likely to be uniform across the country because Brazil covers a very large and diverse geographical area, and the number of inspectors involved is quite small relatively to the demands on their services. Inspectors are also probably very heterogeneous in their ability and honesty (which is important if inspectors are ever offered bribes). ${ }^{10}$ This gives rise to substantial regional variation in the degree of enforcement across cities, which we will explore econometrically. Since we study the effects of enforcement on firm performance, we measure enforcement with the number of firms inspected in each city (in 2002) as a fraction of the total number of firms in the city.

The transportation of inspectors from the subdelegacia to each inspected firm is made using ground transportation (usually by car). Hence, enforcement of the regulation will be

\footnotetext{
${ }^{9}$ The Ministry of Labor continuously provides training to labor inspectors. Moreover, all inspectors have a common implementation manual and work with a similar software. At the end of 2002, there was a total of 2,341 labor inspectors in Brazil.

${ }^{10} \mathrm{Up}$ to $50 \%$ of the inspectors' wage is tied to their performance giving them a strong incentive to penalize all the infractions they can find. However, there is still an incentive to collect bribes.
} 
easier and less costly when there is a subdelegacia in the city (or close to) where the firm is located. To measure the accessibility of inspectors to firms located in different cities, we compute a measure of the cost of travelling from each city to the subdelegacia: the distance from each city to the nearest subdelegacia in the state. When firms are located in cities that have a subdelegacia this measure assumes the value zero. In our empirical work, we instrument our enforcement measure (share of inspected firms in the city) with this variable. ${ }^{11}$ More details on the construction of this variable as well as on enforcement are given in the data appendix.

Labor inspections were not a relevant feature of the Brazilian labor market during the 70's and 80's. In the late 80's the Brazilian economy had several hyperinflation episodes and this contributed to a significant depreciation of the nominal value of the fines. For example, in 1989 the average fine per worker issued by labor inspectors was Reais 70 (at the current exchange rate, USD $\$ 1=1.95$ Reais) while the minimum wage in Brazil was Reais 231 and the dismissal costs could easily go above Reais 700. However, during second half of the 90's labor inspections gained importance. Several reasons are probably behind this. On one hand, labor regulation became stricter after the 1988 Constitution. One the other end, the strong government deficit in the mid 1990s lead the government to search for alternative ways to collect revenue, and labor inspectors began to be used mainly as tax collectors. Their main goal was to collect job security contributions which, even though they cannot be used directly by the government to fund its expenditure, helped reduce the size of the government deficit, at least in an accounting sense. It was probably only after this change that labor inspections gained prominence. ${ }^{12}$

Unfortunately, it is very difficult to gather information about the determinants of the

\footnotetext{
${ }^{11}$ We use data on the distance between any two Brazilian cities from the website www.bbseguroauto.com.br. This website collects very detailed information on distances across cities and is of free access. We compute, the two distances using two alternative measures, one in kilometers and the other in travel hours using ground transportation. In section 4 we present the results for distance in hours but the results are robust to the othermeasures. More details are available in the appendix.

${ }^{12}$ Other reason might be related with the fact that labor inspections react to anonymous reports of misconduct, in most cases by workers. Because Brazil had a military regime up to the 1985, the political environment was not very conducive to worker reporting of employer's misconduct. Moreover, more recently, it has become relatively easy to anonymously report violations of the law to local labor offices, either by phone or through the internet (for those who have access to these means).
} 
location of subdelegacias (as well as their history), although, as we have said already, they tend to be located in large cities. The modern version of these offices seemed to have appeared in the 1970s, at least for the states for which information is available through the Ministry of Labor website. Still, in states such as Rio de Janeiro, some of these local labor offices were created as late as 1997, although this is probably a rare event. We also know that some of the local labor offices created in the 1970s seemed to have replaced smaller local outposts of the Ministry of Labor located in the same city. More than half of the states in Brazil have more than one subdelegacia, with larger states generally having more of these offices. We acknowledge that it would be very useful to have more detailed information about these institutional details, but these have been difficult to assemble.

As we see below, some of our robustness analysis consists in including detailed city characteristics as controls, several of them measured in 1980 (including the proportion of informal workers in the city in 1980, measures of the current institutional development of the city, and distance to the state capital) and in comparing the effect of enforcement for old and young firms (which have made their location decision presumably in times where the importance of local enforcement was quite different), or small and large states (because the variation in the instrument we use is presumably more important in the large states, where more of these offices exist), among several other checks to our procedure.

\subsection{Firm Characteristics}

We use firm level data from the Brazilian Investment Climate survey collected by the World Bank in 2003. The survey is representative of a set of manufacturing sectors (details of the survey are given in the appendix A). Our main outcomes of interest are the value of output, sales, total employment, employment by type of worker (management, qualified worker, nonqualified worker, and non-production worker), the value of capital stock (net of the value of depreciation) and number of workers hired and fired in 2002. Other variables we use in the analysis are industry, age of the firm, share of the firm that is state owned, share of the firm that is foreign owned and the share of female employees. Finally, we know the city where the firm is located, and therefore we can match in this dataset city characteristics as well as 
Ministry of Labor data on the enforcement of regulation at the city level. The final sample has 1,641 firms located in 306 different cities, although several of our regressions use only 1,488 firms for which we have data for all variables. More details on the sample are given in the data appendix.

In order for the firm to participate in the survey it has to be fully registered (as opposed to being an informal firm). Therefore all we will be able to measure is the impact of enforcement on the performance of fully registered firms, although enforcement will probably also have an impact on the performance of informal firms. The effect of enforcement on informal firms is unknown, which is a limitation of our analysis.

From the survey it is impossible to make sure that the firm reports total employment, rather than formal employment only. Given that the available information derives mostly from balance sheet data, it is quite probable that only formal workers are included. However, we measure firm size using different variables (employment, output, sales, capital), and our overall results are similar across measures. We can interpret our results as referring only to formal employment, and given the theory sketched in the next sections, they are likely to be lower bounds to the effects of enforcement on total employment (since increased enforcement leads to a decrease in the share of informal employment).

\subsection{City Level Characteristics}

The final set of variables we include in our regressions are city level measures of output per capita in 1980 , population in 1980 , area of the city, transportation costs, number of train stations, poverty and inequality indices, and a human development index. These are constructed from several data sources and made available at the websites of two major statistical and analysis institutes in Brazil: the Instituto de Pesquisa Economica Aplicada (IPEA), and the Instituto Brasileiro de Geografia e Estatistica (IBGE). Because some of our measures are defined per firm in the city we also construct the number of firms in the city in 2002 . For each city we also calculate road distance (in hours) to the state capital. ${ }^{13}$

\footnotetext{
${ }^{13}$ A major determinant of firms' costs is distance to Sao Paulo (the main economic center in Brazil), according to Lall, Fundenburg and Yepes (2004). Industrial scale is larger close to Sao Paulo (Domingues and Ruiz, 2005). We expect scale to decrease with distance because of the increase in unit production costs.
} 
Finally, we include as controls two indices of institutional development in the city, used (and generously provided) by Naritomi, Soares and Assuncao (2007). The first measures the quality of local administration, and it is an index created by IBGE and used by the Ministry of Planning to monitor the administrative performance of municipalities. The second (also created by IBGE) measures the penetration of the rule of law, in particular the existence of courts or justice commissions in the city. For more detail see Naritomi, Soares and Assuncao $(2007)$

Sample statistics for the main variables we use are presented in table A.1.in the appendix. The average firm in the sample has 125 workers, hired 36 workers in the previous year and fired 26 workers. About 38\% of its workers are females. The average firm is also 18 years old, has a share of state ownership well below $1 \%$ and a share of foreign ownership of about $4.5 \%$. The average firm is located less than half an hour away from the nearest subdelegacia. In the city where the firm is located, 7.7 firms per 100 firms were visited by a labor inspector last year, $85 \%$ of the population lives in an urban area, and there are about 960000 inhabitants in 1980 (so we clearly have an oversample of large and urban cities).

\section{Theoretical Background}

We consider a (formal) firm choosing labor and capital (and perhaps even the technology of production). With strict regulation and imperfect monitoring, firms can either choose to comply with regulation, or they can overcome the law. The benefits of evasion relate to the monetary savings of not paying the monthly mandatory contributions to the FGTS, not having to comply with health and safety instructions, avoiding severance payments and taxes, and other employment costs. Furthermore, when firms evade regulation and hire informal workers they will also benefit from the additional flexibility in the labor force to adjust to shocks for example, to lower hiring and firing costs (Oi, 1962, Hammermesh, 1989, Micco and Pages, 2006), or to the lack of regulation in working hours. On the other hand, the costs of evasion relate to the probability of being caught in labor inspections (for given firm characteristics) and having to pay a fine. As enforcement becomes stricter, the cost 
of evading labor regulation increases and, all else constant, there should be a reduction in the evasion of regulation. Our conjecture is that the higher labor costs (or the less flexible labor) faced by firms which must comply with labor regulations will affect the operation of the firm.

As explained in the previous section, increased enforcement directly affects the cost of labor because stricter enforcement is associated with higher compliance with the mandatory payments to the FGTS fund and with the health and safety regulations in the firm. These higher costs of labor, together with the higher adjustment costs associated with formal contracts, are likely to be important constraints to firm size, and more importantly, to firm growth. As for the effect on capital, it depends on its substitutability or complementarity with labor, the strength of scale effects, and on potential hold-up problems (e.g., Besley and Burgess, 2004).

There is another reason why firms have an incentive to remain small in the presence of enforcement. Even if all firms are fully registered (as it is the case in our sample), smaller firms are less visible and their evasion of the law is more likely to be undetected. Moreover, since inspectors' pay is tied to their performance, they have an incentive to visit larger firms, where they are more likely to find at least one violation, and where the size of violations is likely to be larger, because of the firm's scale.

\section{Enforcement of Labor Regulation and Firm Performance}

\subsection{Main Findings}

As argued above, we think of firms weighting the benefits and costs of not complying with labor regulations. The benefits of not complying with labor regulation relate with paying lower labor taxes (even to formal workers) and to a having a more flexible labor force (possibly through a higher number of informal workers). As enforcement becomes stricter the cost of evading labor regulation increases and, all else constant, the probability evading the law is likely to be reduced. Firms may respond to increased enforcement in several ways. For example, they may choose capital intensive technologies when enforcement is strict (avoiding large labor costs) and labor intensive technologies when enforcement is loose (Loayza, 1996). 
Alternatively, whenever enforcement is loose, firms can choose technologies that are more productive when labor is flexible, and these can be either labor intensive or capital intensive. Besley and Burgess (2004) find that pro-worker labor regulation in India (which makes labor more expensive) leads to lower investment, employment and labor productivity in the formal sector. Scarpetta and Tressel (2004) present evidence suggestive that the negative effect of labor regulation on productivity works through a reduction in the incentives for innovation and technology adoption.

In this section we analyze the relationship between enforcement of labor regulation and alternative indicators of firm performance in Brazil. In particular, we estimate the following equation:

$$
Y_{j c}=\beta E_{c}+X_{j} \gamma+Z_{c} \delta+\varepsilon_{j c}
$$

where $Y_{j c}$ is the outcome of interest (output, employment, capital stock) for firm $j$ in city $c, E_{c}$ is enforcement of worker's registration in subregion $c$ (measured by the number of inspected firms per 100 firms in the city), $X_{j}$ is a vector of firm characteristics (age of the firm, share of public capital, share of foreign capital and industry dummies) and $Z_{c}$ are demographic, institutional and economic controls at the city level. In particular, we include in $Z_{c}$ the distance (in hours) between the city $c$ where the firm is located to the state capital city. We cluster all standard errors at the city level.

Since $E_{c}$ is potentially correlated with $\varepsilon_{j c}$ (either because more violations of labor law will attract more enforcement, or because more developed areas have better institutions and higher enforcement), we adopt an instrumental variable strategy. Our instrument is the distance between the city where the firm is located and the nearest cities with a subdelegacia in the state. Whenever the firm is located in a city where a labor office is located the distance is set to zero. Distances are measured in hours of travel by car, the type of transportation used by labor inspectors (for a detailed description see the appendix B). ${ }^{14}$

We include in the model a detailed set of city characteristics to account for differences across cities, including state fixed effects Most important are the distance to the state capital,

\footnotetext{
${ }^{14}$ In the appendix (Table A4) we present alternative results where we change the endogenous variable from being the log of inspections to the level of inspections. Our main results stand.
} 
which is meant to capture distance to markets and to other types of institutions, and two indices of institutional quality in the city, one measuring access to justice, and the other measuring the quality of local administration.

Table 1 presents the results of a regression of the share of firms receiving a labor inspection in the city where firm $j$ is located on city and firm characteristics, and on the average distance to a labor office (the instrumental variable). All the specifications include state dummy variables, city characteristics, as well as other firm controls (age of the firm, share of public capital, share of foreign capital and industry dummies). Each column corresponds to a specification of the model including different sets of city controls. The city level controls in column (1) are the log of GDP per capita in 1980, population in 1980, and the distance between the city where the firm is located to the state capital city. These controls are meant to capture the main city characteristics that are likely to determine both the location of subdelegacias and of firms: city size, average income, and distance to markets. These variables are measured in 1980 because this is the time we expect that local labor offices began exerting most of their influence on firms' behaviors. We have estimated specifications with the controls measured both in 1970 and in 2000, and the results were essentially unchanged. We chose to measure city level controls as early in time as we could (without losing too many observations), in an attempt to use predetermined variables. Contemporaneous measures of city characteristics may be endogenously affected by current enforcement. Still, we include two contemporaneous measures institutional quality, because past data on this is not available, and because these variables are not very likely to be affected by the enforcement of labor regulation. We also control for the percentage of the population in the city which can be considered urban, as well as the city area. Once again, these variables are meant to measure the relative importance of the city, both in terms of size and of economic development.

Column (2) adds an index of transportation costs (to the nearest capital, which is not necessarily the state capital) and the number of train stations in the city. These variables, as well as distance to the state capital, measure accessibility of the city, which is another potential determinant of the location of government bureaus and of firms. Finally, column (3) adds a poverty index, mortality index and inequality index in 1991, and column (4) adds 
an index of human development, also measured in 1991 (which is designed to measure health and education outcomes in the city). The idea is to compare cities with the same level of development, but with varying degrees of enforcement. See appendices for the sources and definition of the variables.

We run the first stage regression at the firm level even though the dependent variable varies only at the city level. The reason is that this is the first stage regression of our instrumental variables procedure, which is at the firm level (although in section 5.3 we will also present city level results based on Census data). All standard errors we present are clustered at the city level. The coefficients in the table show how the probability of a firm being inspected changes with city level characteristics. At the bottom of each column we present the F-statistic for the test of whether the instrument belongs in the regression, and the corresponding p-value. These results show that the instrumental variable is a very strong predictor of the incidence of labor inspections in the city. Our assumption is that the instrument measures the cost of enforcement in each city, and that conditional on the set of controls we include in the regression the instrument is not correlated with any of the dependent variables of interest (except through enforcement). In section 5.2 we discuss in detail the potential problems of our empirical strategy, try to address them, and present some arguments suggesting that the procedure is valid. Our first stage results are of interest in their own right, and indicate an elasticity of enforcement with respect to access of $0.07\left(=\frac{1}{1.6} * 0.11\right.$, where 1.6 is the average distance in our sample). This estimate is remarkable stable across specifications, suggesting that we have adequately controlled for the determinants of the location of labor offices.

We start by analyzing the case where $Y_{j c}$ is $\log$ total employment in the firm in $2002 .{ }^{15}$ Table 2 presents the results of estimating the regression of log firm employment on city level labor inspections and on the city and firm level controls. Column (1) reports the least squares estimates and columns (2) to (5) report the instrumental variable estimates using the average distance to all the subdelegacias in the state (and controlling for other city level

\footnotetext{
${ }^{15}$ Although we do not estimate an explicit labor demand function, the (reduced form) relationship we estimate between employment and enforcement can be derived from a well defined profit maximization problem (keeping prices fixed).
} 
characteristics). The least square estimate is slightly negative and insignificant, but all the IV estimates are strong and negative.

In our main specification (column (2)) the elasticity of size with respect to enforcement is -0.477 . This elasticity is quite reasonable and, if anything, it seems small. As a very rough benchmark comparison, consider a firm with a Cobb-Douglas production function:

$$
Y=A K^{1-\alpha} L^{\alpha}
$$

where $\alpha$ (the labor income share) is $0.6, Y$ is output, $K$ is capital and $L$ is labor ( $A$ is a productivity parameter). From the first order conditions of the firm's problem we obtain

$$
\ln W=\ln \alpha A+(1-\alpha) \ln K+(\alpha-1) \ln L
$$

where $W$ is the wage rate. If $K$ is fixed, then

$$
\frac{\partial \ln L}{\partial \ln W}=-\frac{1}{1-\alpha}=-2.5
$$

and this number is likely to be smaller if $K$ is flexible.

Of course, the Cobb-Douglas benchmark with $\alpha=0.6$ and no adjustment costs is probably not the correct one. Even if it were, a small elasticity could be explained: if capital can adjust (which happens in reality, as we see next), then the elasticity of total labor costs with respect to the wage rate may be less than $1 \%$; or perhaps our employment data is only capturing formal workers, as opposed to the whole labor force. ${ }^{16}$

In theory the sign of the OLS bias is not clear. One one end, there can be more inspections in cities where informal employment is more prevalent. Since informal firms tend to be smaller so that they can evade detection more easily, a high level of inspections will be associated with high levels of informality and small firm size. However, it could also happen that inspections are more frequent where institutions are more developed, and this happens in richer cities with low levels of informality. In that case a high level of inspections would be simultaneously associated with low levels of informality and high levels employment. Other similar stories are possible.

\footnotetext{
${ }^{16}$ On the other end, if firms choose to be smaller to avoid detection (on top of the increase in labor costs), then we would expect this number to be larger than what is implied by the elasticity of demand (from a demand curve).
} 
The estimate of the elasticity of employment with respect to enforcement changes slightly as we add more controls to the model, but the overall pattern is similar across columns. Therefore in the rest of the paper we proceed with specification in column (2). There, we control for distance from each city to the state capital, institutional development of the city, $\log$ output per capita in the city in 1980 , population in the city in 1980, share of urban population in the city in 1980, city area, state dummies, industry dummies, age of the firm, share of the firm state owned, share of the firm foreign owned.

Table 3 presents our main set of results for different measures of firm performance. We present instrumental variables estimates of equation (5.1) for log employment, log value of output, log sales, log value of the stock of capital (all measured in 2002), and log number of employees hired or fired (between 2001 and 2002). ${ }^{17}$ The number of observations varies slightly across columns because we do not observe all outcomes for all firms. Our estimates indicate that an increase of $1 \%$ in labor inspections in the city where the firm is located leads to a $0.47 \%$ reduction in firm employment, a $0.48 \%$ reduction in output, a $0.46 \%$ reduction in sales, and a $0.38 \%$ reduction in the number of new hires. There is also a $0.52 \%$ reduction in the stock of capital, and a $0.12 \%$ reduction in the number of employees fired, but these coefficients are not statistically different from zero.

These estimates indicate that high levels of enforcement lead to smaller firms, with lower labor turnover, and lower output. We suggest that this is because stricter enforcement is equivalent with stricter labor regulation, high labor costs and low flexibility. These results indicate a reduction in firm size, and it is likely that they are also associated with a reduction in overall employment. Several other papers in the literature, such as Besley and Burgess (2004) and Heckman and Pages (2003), also conclude that strict labor regulation is associated with low levels of employment and economic performance. However, it is not clear from our results whether the direct effects of enforcement on productivity are strong, although there are probably indirect effects on firm growth because of constraints on firm size. We come back to this point below. It also remains to be shown whether increased enforcement is also

\footnotetext{
${ }^{17}$ The least squares estimation of equation (5.1) for the different outcomes of interest is reported in table A.3. in the appendix.
} 
associated with lower levels of illegal employment. Before we turn to these two issues, we provide an additional discussion of the sensitivity and credibility of our empirical strategy.

\subsection{Robustness and Validity of the Instrumental Variable}

In our main specification, our identification strategy is to compare different firms within the same state and industry, with similar characteristics in terms of age and ownership structure, located in cities of the same size and income per capita, with the same level of urbanization, which are equally far from the state capital, have similar levels of access to justice and quality of public management, but which differ in their distance to the nearest enforcement office (we include additional controls in several of our specifications). The validity of our instrumental variables procedure would be violated if the firm and city characteristics we include in the regressions were not enough to account for the fact that labor offices are not randomly distributed across cities, and firms are not randomly located across cities. It is reassuring that, as shown in table 2, the inclusion and exclusion of different control variables does not affect the employment regressions substantially. The same is true of the other firm outcomes we discuss (available on request).

The city level variables we use as controls provide an extensive and detailed description of each city, which hopefully are good indicators of the city development, and how likely it is to host both regional offices of the government and different types of firms. Furthermore, our most important city level controls are measured in 1980, roughly 20 years before the firm level data we use was collected. Even though it is quite difficult to gather information on this topic, most subdelegacias did not exist in their current format until the 1970s. There are however several accounts of subdelegacias which were created on top of a previously existing local office of the Ministry of Labor. More importantly, the location of labor offices for firms gained much of its current importance quite recently. As mentioned above, the importance of the enforcement of regulation increased over time for different reasons (e.g., Cardoso and Lage, 2007).

The firm controls used include age of the firm, share of public capital, share of foreign capital and industry dummies. Again, our assumption is that these variables, along with the 
city characteristics we already described, are enough to account for the location decision of the firm. Indeed, it is quite likely that age of the firm and industry are two very important determinants of firm location.

There may still be some concern that remaining unobservables are driving both the location and outcomes of firms. Therefore, we conducted several exercises which suggest that our empirical strategy is valid. We start by presenting table 4, where we examine what happens when we divide workers into four categories (management, skilled workers, unskilled workers and non-production workers), and then analyze how the employment of each type of worker varies with the enforcement of labor regulation. The first column of the table shows our basic result using total employment in the firm, and columns (2) to (5) show results by type of worker. As argued above, enforcement of labor regulations in Brazil is primarily related with the compliance of the labor taxes related to the dismissal fund (or FGTS). Every month, the employer augments the worker's accumulated FGTS account by contributing with a percentage of his/her wage. Therefore, the benefits of evading the law for firms are, in absolute value, higher for skilled workers with higher wages. Nevertheless, skilled workers also have more bargaining power than unskilled workers, which are in more abundant supply. Therefore, firms are more likely to be able to avoid these regulations mostly for the unskilled workers, with more limited outside options. By the same argument, most violations of other features of the labor market regulations such as health and safety regulations or having the official work permit are more likely to be more important for this type of employees. Therefore, enforcement should be related mostly to the employment of unskilled workers. Table 4 shows that this is precisely the case: almost all of the employment decline is concentrated in unskilled workers.

Even though the location of employment offices is quite stable over time, occasionally an old office is closed down and a new office opens somewhere else. Furthermore, we argued that the role of enforcement has probably increased since the 1980s. Young firms have made their location decision very recently and therefore could have responded more easily to the recent intensity of enforcement observed in each city, to the importance of the labor office for the intensity of enforcement, and to the availability of the labor office in the city. In contrast, 
older firms made their location decision much earlier, and since then we do not expect firm migration to be a frequent event. We split the sample into young (less or equal than 20 years of age) and old (more than 20 years of age) firms, and then re-estimated our models for the two subsamples. The results are presented in table 5, with panel A corresponding to old firms and panel B corresponding to young firms. The magnitude of our estimates is larger once we omit young firms from the sample, and results are quite weak for the sample of young firms. This may happen because our results are driven by the exogenous location of old firms (with limited mobility in response to enforcement or other concerns), not by the (perhaps) endogenous location of young firms. This could explain why the estimated elasticities are apparently small in our benchmark models.

We also checked the robustness of the main results to the exclusion of the largest cities from the sample. Enforcement offices tend to locate mainly in large cities and one might worry that our results were being driven mostly by unobserved differences between cities of different sizes (we control for city size and average income, among other variables) other than differences in enforcement. In panel $A$ of table 6 we delete from our sample all firms located in a state capital (which all have a delegation of the Ministry of Labor), while in table $\mathrm{B}$ we delete all firms located either in a state capital or in a city with more than 1 million inhabitants. The estimates in panel A are similar to the estimates of table 3 (if anything, they are more pronounced than in table 3), and so are those of panel B. These results suggest that our set of control variables may be sufficient to account for the major differences between cities with and without enforcement agencies.

We examine whether firms that locate close to labor offices are different than firms that locate far from labor offices in dimensions other than employment, capital and output, after controlling for city characteristics and industry dummies. In particular we examine the correlation between the average distance to the subdelegacia and variables such as: age of the firm, share of the firm that is state owned, share of the firm that is foreign owned, and share of females in the labor force. If firms that located close to enforcement offices were fundamentally different than other firms, we would expect to observe differences in all these variables. 
The results of this exercise are presented in table 7 . We do not find statistically significant effects of the instrument on most of these variables. The only exception is share of foreign ownership but the magnitude of the coefficient is close to zero. This suggests that firms that locate in cities with and without an enforcement office are similar after controlling for city characteristics and industry. Furthermore, as also seen in table 3 , there is no visible difference in wages paid by firms located near and far away from labor offices. This indicates that the estimated differential scale of the firms is not driven by differences in wages, but perhaps by differences in labor costs due to regulation. As mentioned before, this finding is somewhat striking because we would expect stricter enforcement to have an effect on wages as well as on employment. However, empirically this is not the case, and this is consistent with the weak effects we find both for labor productivity and for capital intensity, or with a model where there is some factor price (wage) equalization across cities.

Finally, in appendix table A5 we rerun our main models using as dependent variables perceptions of the manager with regards to (local) constraints to firm growth. We focus on two main type of constraints: tax rate, and tax administration. The manager of the firm was asked how much of a barrier to the firm's operation were each of these three problems. The answers to these questions were originally coded from 0 to 4,0 indicating that the constraint is not important, and 4 indicating that it is very important. ${ }^{18}$ We recoded these variables to be dummy variables, which take value 1 only if the original variable takes value 4 (i.e., if the constraint is perceived as very damaging for growth). We find that labor inspections are bit associated with perceptions of high tax rates or constraining tax rules. Even though this evidence is only suggestive, it reassures us that the variation that is driving our results is related to labor regulation, as opposed to other types of regulations.

One can also conjecture what would be the direction of any possible remaining bias. On one end, as emphasized in Lall, Funderburg and Yepes (2004), transport costs are a major

\footnotetext{
${ }^{18}$ The exact wording of each of the question is something like the following: "How much is each of the following an obstacle to the operations and growth of your business?". Then the manager is given a list of potential obstacules among which are: i) Tax Rate; ii) Tax Administration (tax authorities). The manager can give five possible answers: not an obstacle, small obstacle, moderate obstacle, large obstacle, severe obstacle.
} 
determinant of production costs in Brazil, possibly a constraint to firm scale (Domingues and Ruiz, 2004). Therefore, it is unlikely that the largest firms locate away from large markets. In this case, we would expect any bias to go against our main findings. However, it may also happen that larger firms, who have the strongest incentive to avoid regulation because of labor costs, choose to locate away from cities where enforcement is strong, which would mean that the absolute size of our estimates is too large. Nevertheless, the latter story would only be true if regulation has a meaningful effect on firm costs (otherwise they would not try to avoid it), and even though our estimates would be too large in such a case, they would still have the correct sign.

It is important to acknowledge that enforcement can affect the firm's behavior through several mechanisms, and our paper so far only emphasizes one of them. First, there are many more ways to violate the labor code beyond not complying with payment of labor taxes or with health and safety inspections. Indeed several aspects of firm's employment activities are regulated, and may imply severe constraints on the firms' operations. In particular, an alternative story of why stricter enforcement could lead to reduced firm size is through the reduced use of informal workers. Informal workers can be cheaper and more flexibly adjusted than formal workers. Second, corruption may be associated with enforcement. In particular, in cities with high levels of enforcement there are more opportunities for corruption since the interactions between firms and government inspectors are likely to be more intense than in cities with weaker enforcement.

Finally, one could argue that stricter enforcement could lead to a composition effect associated to the types of firms observed in our sample. For simplicity, assume that the distribution of firm size is the same across all cities. Cities might differ in the degree of enforcement. Assume also that stricter enforcement of labor regulations leads to a higher probability of a firm being formal. Under this scenario, comparing firms in cities with different degrees of enforcement would necessarily lead to a smaller firm size in cities with stricter enforcement. The reason is because, when enforcement is stricter there will be a larger share of formal firms and the average size of a formal firm will be smaller. Nevertheless, we argue that it is very unlikely that in Brazil enforcement of labor regulations is closely related 
to the formal registration of firms because, as explained in sections 2 and 3 , enforcement is mostly about the enforcing the mandatory payments to the FGTS, and the health and safety inspections.

\subsection{Enforcement of Labor Regulation and Informal Labor and Unemployment at the City Level}

In section 5.1 we showed that enforcement of labor regulation is strongly associated with the firm's total employment, number of new hires, capital stock, output and labor productivity. We argued that the mechanism is the following: when firms face stricter enforcement of regulation their access to informal workers is diminished. Since informal workers are both cheaper and more flexible than formal workers, diminished access to these workers hurts firm performance. In this section we present evidence that in cities where the enforcement of regulation is stricter informal employment is lower, and the unemployment rate is higher. Since we do not have an objective measure of informal employment in the firm level dataset that we use, we rely on data from the 2000 Census to construct the proportion of the labor force that is informal in each city. The unemployment rate comes from the same source, and it is constructed by IPEA.

We start by estimating the following equation:

$$
\frac{\operatorname{Inf} f_{c}}{E m p_{c}}=\beta E_{c}+Z_{c} \delta+\varepsilon_{c}
$$

where $\frac{I n f_{c}}{E m p_{c}}$ is the proportion of informal workers in the total employment of city $c, E_{c}$ is the $\log$ number of inspections per 100 firms in the city and $Z_{c}$ includes city level controls (the $\log$ of output per capita in the city in 1980 and total population in the city in 1980). All specifications include state level dummy variables. Again we instrument enforcement with the average distance to the subdelegacias in the region controlling for the distance between each city $c$ and the state capital city. All the specifications weight each observation with the total population in each city. We expect that $\hat{\beta}<0$ since increasing the enforcement of worker's registration, increases the cost of using informal labor. We define informal workers as those who report working without a work permit, and those who are self employed. This is the standard definition of informal worker. Note that, on average, each city had 4 inspections 
per 100 firms in 2002.

We also estimate the following model:

$$
\frac{U n e m p_{c}}{E m p_{c}}=\beta E_{c}+Z_{c} \delta+\varepsilon_{c}
$$

where $\frac{U n e m p_{c}}{E m p_{c}}$ is the unemployment rate of city c. For consistency with the rest of the paper, we only use the states we used in the earlier sections of the paper (for which we have firm level data). We note however that this is a minor constraint.

Table 8 reports the estimates of equations (5.2) and (5.3) (top and bottom panels, respectively). Column (1) presents the least squares results, and shows that there is an apparent negative correlation between labor inspections and informal employment, but no correlations with unemployment. However, least squares estimates can be biased for several reasons. For example, if more informality leads to more inspections then in the cross section there may be no correlation between these two variables, or even a positive correlation (as in Levitt, 1997).

Therefore, we instrument labor inspections with the distance to the nearest delegation of the Ministry of Labor, as we have done so far in the paper. Column (2) presents the estimates of the reduced form regressions of the relevant dependent variable on the instrument and city level controls. It shows that a one hour increase in the distance to a labor office is associated with a $1.3 \%$ increase in the proportion of informal employment in the city $(38 \%$ of the workers in the average city are informal), and a $0.2 \%$ decrease in the unemployment rate (which is around $11 \%$ in the average city). Column (3) corresponds to the first stage regression, and shows that an increase in the distance to an enforcement office by one hour is associated with a $11.4 \%$ decrease in the number of inspections per 100 firms in the city (on average there are 3.89 inspections per 100 firms in the city). This is smaller than our estimate in table 1 , but in this regression the city is the unit whereas in table 1 the firm is the unit. Finally, column (4) presents the instrumental variables estimates of equations (5.2) and (5.3). It shows that a $1 \%$ increase in the number of inspections per 100 firms in the city leads to a 11 percentage point reduction in the proportion of informal workers, and a 1.5 percentage point increase in the unemployment rate in the city. 
In summary, stricter enforcement of labor regulation leads to lower levels of informal employment, and higher unemployment rates. Based on our estimates from this and the previous sections we argue that stricter enforcement of regulation reduces the access of firms to informal employment, thereby increasing their employment tax costs, their employment adjustment costs, and adversely affecting their output and investment.

Finally, it is important to acknowledge that enforcement can affect the firm's behavior through several mechanisms, and our paper so far only emphasizes a few of them. Corruption may also be associated with enforcement. In particular, in cities with high levels of enforcement there are more opportunities for corruption since the interactions between firms and government inspectors are likely to be more intense than in cities with weaker enforcement.

\section{Conclusion}

The paper analyses how enforcement of labor regulations affects firm performance. Our prior is that stricter enforcement increases the cost of labor through the compliance with mandatory labor contributions and health and safety inspections, which in turn can damage firm productivity. Using a combination of firm level data on firm performance, city level data on distances and institutional quality and administrative data on enforcement of regulation, we show that law enforcement reduces firm (measured by employment, output, sales or capital stock) and possibly productivity. We argue that this is likely to be caused by higher labor costs, although it could also be driven by a more limited access to flexible labor.

Constraints to firm size can be synonymous to constraints to economic growth if, as shown in Rajan and Zingales (1998), most economic growth is due to the growth of existing firms, not to the appearance of new firms. Furthermore, the negative effects of enforcement on firm size (especially when we measure the size in terms of number of workers) are also likely to be associated with negative effects on overall employment. Our analysis also suggests that increased enforcement can lead to lower labor productivity and lower capital intensity, but the estimated effects are imprecise, and smaller than those on firm size.

Still, the crucial variable constraining the activity of firms is not enforcement per se, but 
strict labor laws. In the presence of a balanced regulatory environment higher enforcement is likely to be associated with better, not worse performance, because it leads to better institutions. Only in this special case where labor laws are unduly restrictive can looser enforcement be helpful for economic efficiency, by allowing firms to operate outside the stringent set of labor laws. In summary, our paper shows that stricter enforcement of labor regulations decreases average firm size, through higher labor costs. Nevertheless, one should be cautious about the policy implications of the paper. The evasion of labor regulations in Brazil (reflected, for example, in the widespread informal employment) may not only be a manifestation of weak institutions, but also an equilibrium response to unreasonably stringent labor regulations. Compliance with the law can be more easily affected by changes in the law than by changes in enforcement. Furthermore, increasing enforcement without changing the law may lead to very rigid labor markets and poor economic performance. However, our paper does not imply that evasion is necessarily desirable. Systematic violations of the law weaken the country's institutions and can hurt development in the long run. Therefore, if we thought regulation to be detrimental to firms, a possible recommendation for fostering growth in Brazil would be to promote more flexible labor laws, rather than advocating a more relaxed enforcement environment.

\section{Appendices}

\section{A. Data Sources}

The firm level data used is the Brazilian investment climate survey collected by the World Bank in 2003. ${ }^{19}$ The survey covers thirteen Brazilian states: Sao Paulo, Rio de Janeiro, Minas Gerais, Santa Catarina, Rio Grande do Sul, Parana, Goias, Mato Grosso, Ceara, Paraiba, Maranhao, Bahia and Amazonas. ${ }^{20}$ The criteria used for the sample selection was the representativeness of the population in the specified industrial and regional categories, and diversity in the firm size. To account for these considerations a random sample was stratified using employment has weights. The sample frame covered all the registered firms

\footnotetext{
${ }^{19}$ Previous similar data projects within the World Bank include the Regional Program on Enterprise Development, that has been collecting firm-level data in Sub-Saharan Africa countries for a decade, and the World Business Environment Survey.

${ }^{20}$ Brazil is divided into 5 regions (North, Northeast, Center-West, Southeast and South) and 27 states.
} 
in the following industrial sectors: food, textile, garments, chemicals, machinery, electronic equipment, auto components and wood products. The selected industries together account for more than $75 \%$ of the manufacturing value added and employment in 2002. The first part of the survey, collects information on different topics: general information about the firm and its manager, business environment and business relations, services and government regulations, labor and human resources, production capacity, planning and innovations, supplier and client relations, infrastructure and services inspections, finance. The second part of the survey collects balance sheet information for the 2000-2002 period.

In the collection of this dataset the World Bank worked with a private survey firm. Given the detail and the sensitive nature of some of the questions the survey was designed to be answered by the firm's manager. The typical observation is based on a three-hour interview which often implied two visits to the firm to accommodate the manager's time schedule. This resulted in a sample of 1,641 firms (located in 306 different cities) with information on several characteristics of the firm, such as total employment, sales, value added, labor costs, capital stock, share of high educated workers, share of workers with training, age of the firm and share of foreign and public ownership.

Data on the enforcement of labor regulation in 2002 comes from the Brazilian Ministry of Labor. Finally, we also use information from two Brazilian statistical and research institutes (IPEA and IBGE). Data for population in 1980 and for the total number of plants in 2000 and 2002 is collected by the National Statistics Institute (IBGE) at the city level. City level data for GDP (1980, 1996, 2000), urban population (1980), share of females (2000), geographical area (2000), index in transportation costs to the nearest capital city (1995), number of train stations in the city (1995), poverty index in the city (1991), mortality index in the city (1991), Theil income inequality index in the city (1991) and the human development index in the city (1980) (average of the education, income and age indexes) are all collected by the Instituto de Pesquisa Economica Aplicada (IPEA).

The construction of the main variables in the paper for 2002 was as follows: Employment is the total number of workers in the firm in 2002, Sales per employee is the total sales divided by total number of employees, Output per employee is the firm's output divided 
by the total number of employees, Capital per employee is total value of machinery and equipment at the end of 2002, excluding depreciation, divided by total number of employees, Share of high educated workers is the share of workers with at least the secondary education, Share of females is the share of females in total workforce, Share public (foreign) ownership is the share of the firm's capital owned by public (foreign) owners. We construct GDP per capita in the city dividing GDP by the total population in the city, Average firm size in the city dividing total employment by the total number of firms in the city and Output per firm in the city dividing total GDP by the total number of firms in the city. Population is normalized by 1,000,000 inhabitants, City area is normalized by 1000 squared kilometers and Urban population is the share of urban population in the total city population.

\section{B. Enforcement of Labor Regulation}

The Brazilian Ministry of Labor has the responsibility to enforce all the laws and regulations, including international conventions, related with labor and employment relations and contracts. The inspectors verify the enforcement of labor related laws and regulations. In particular, they verify whether workers are formally registered with the labor authorities, i.e., that they have a work permit (or carteira de trabalho). The Ministry of Labor is a decentralized structure with a regional branch in each state (delegacia regional do trabalho). Within each branch, there are several administrative units, or subdelegacias. The concept of subdelegacia is administrative and does not correspond to any geographical unit. In particular, a subdelegacia includes more than one city (or municipio). In each subdelegacia there are several regional offices (called agencias de atendimento), of which one is the headquarters. The regional offices are not decision units like the subdelegacias. They are designed for increasing the access of the public to the Ministry of Labor.

The inspector responsible for each subdelegacia, or the subdelegado, reports to the inspector responsible for the regional branch, the delegado. The labor inspectors are affiliated only with one subdelegacia. In general, each inspector works only for one subdelegacia and reports to the subdelegado. The inspectors visit the plants with the objective of evaluating the compliance with several dimensions of the labor laws and regulations. They administer different types of labor fines: informal worker fines, are fines related with the firm not 
registering the worker for a work permit, work load fines are fines related with the firm not complying with the official work load, wage fines are fines related with the firm not paying the minimum established by the law, hours of work fines are fines related with the firm not complying with the number of hours of work and the mandatory pauses, FGTS fines are fines related with the firm not making the mandatory discounts to the FGTS, transport subsidy fines are fines related with firm not paying the mandatory transport subsidy, and other fines are fines related with other mandatory obligations of the firm to their workers. Our measure of enforcement will be based on the administrative data collected by the Ministry of Labor (2002) on the total number of inspected firms at the city level. To obtain our enforcement measure we divide the total number of inspected firms at the city level by the total number of firms in the city and multiply by 100 .

To instrument enforcement we use a measure of how costly is the access of inspectors to firms in different cities. We compute the distance between any Brazilian city and a subdelegacia in the same state. We use data on the distance between any two Brazilian cities (in kilometers and in travel hours using ground transportation) from the website www.bbseguroauto.com.br. For each city we compute two alternative measures: (1) Distance to the closest subdelegacia within the region (2) Average distance to all the subdelegacias within the region. When the firm is located in a city with a subdelegacia both measures assume the value zero since there is no displacement cost for the inspectors. We also construct the distance (in hours) between each city and the state capital city.

We faced two obstacles in these computations that nevertheless affected very few cities. On the one hand, some of the firms in our sample are located in cities that only recently became officially recognized as cities. For these, we did not have information on the website. To fill out this gap, we have used maps to find the nearest city and then used their information as an approximation. (there were few of these cases and calculations are available upon request). On the other hand, the majority of cities in Amazonas use mostly the maritime transportation rather than the ground transportation both for goods or persons. Thus, for Amazonas there is also no information on the ground distance between cities. There were only two firms located outside Manaus. Since these cities were very close to Manaus, and in 
Manaus there is a subdelegacia, we assume that the distance is zero. 


\section{References}

[1] Acemoglu, Daron, "Good Jobs versus Bad Jobs", Journal of Labor Economics, 19(1) (2001), 1-21.

[2] Acemoglu, Daron and James Robinson, "Persistence of Power, Elites and Institutions", NBER Working Paper 12108 (2006).

[3] Ahmad, Ahsan, and Carmen Pagés, "Are All Labor Regulations Equal? Assessing the Effects of Job Security, Labor Dispute and Contract Labor Laws in India," Policy Research Working Paper 4259. Washington, DC, United States: World Bank (2007).

[4] Almeida, Rita and Carneiro, Pedro. "Inequality and Employment in a Dual Economy: Enforcement of Labor Regulation in Brazil". IZA Working Paper number 3094 (2007).

[5] Amin, Mohammed, "Labor regulation and employment in India's retail stores," Policy research working paper 4314, The World Bank, Washington DC (2007).

[6] Autor, David, William Kerr and Adriana Kugler, "Do Employment Protections Reduce Productivy? Evidence from U.S. States", NBER Working Paper 12860 (2007).

[7] Barros, Ricardo Paes and C. Corseuil, " The Impact of Regulations on Brazilian Labor Market Performance", in James Heckman and Carmen Pages, eds., Law and Employment: Lessons from Latin American and the Caribbean, NBER Conference Report series, Chicago and London: University of Chicago Press, 2004, pp 273-350.

[8] Besley, Timothy and Robin Burgess, "Can Labor Regulation Hinder Economic Performance? Evidence from India", Quarterly Journal of Economics, CXIX (2004), 91-134.

[9] Blanchard, Olivier, and Pedro Portugal, "What hides behind an unemployment rate. Comparing Portuguese and US unemployment", American Economic Review, 91, 1: 187-207 (2001).

[10] Blanchard, Olivier and Justin Wolfers, "The role of shocks and institutions in the rise of european unemployment: aggregate Evidence", Economic Journal, CX(2000), 1-33.

[11] Boeri, Tito and Juan Jimeno, "The Effects of Employment Protection: Learning from Variable Enforcement", European Economic Review, XLIX (2005), 2057-2077.

[12] Botero, Juan, Simeon Djankov, Rafael La Porta, Florencio Lopez-de-Silanes, and Andrei Shleifer, "The Regulation of Labor", Quarterly Journal of Economics, CXIX(2004), $1339-1382$.

[13] Cardoso, Adalberto, and Telma Lage, 2007. "As Normas e os Factos". Editora FGV, Rio de Janeiro, Brasil.

[14] Gruber, Jonathan, "The Incidence of Payroll Taxation: Evidence from Chile", Journal of Labor Economics, XV(1997), 72-101.

[15] De Paula, A. and J. Scheinkman, "Informal Firms", working paper. 
[16] De Soto, Hernando, The Other Path: The Invisible Revolution in the Third World, (New York: Harpercollins, 1989).

[17] Djankov, Simeon, Rafael La Porta, Florencio Lopez-de-Silanes, and Andrei Shleifer, "Courts," Quarterly Journal of Economics, 118, 2: 453-517 (2003).

[18] Djankov, Simeon, Caralee McLiesh, and Andrei Shleifer, "Private credit in 129 Countries," Journal of Financial Economics, 84, 2: 299-329 (2007).

[19] Domingues, Edson and Ricardo Ruiz, "Industrial Cores and Peripheries in Brazil", UFMG Working Paper (2005).

[20] Elmeskov, Jorgen, John Martin and Stefano Scarpetta (1998), "Key Lessons for Labour Market Reforms: Evidence from OECD Countries' Experiences", Swedish Economic Policy Review, 5 (1998)

[21] Fields, Gary, "Dualism in the Labor Market: a Perspective on the Lewis Model After Half a Century", The Manchester School, 72(6) (2004)

[22] Freeman, Richard, "Labor Market Institutions and Economic Performance", Economic Policy, VI (1988), 64-80.

[23] Fugazza, Marco and Jean-François Jacques, "Labor market institutions, taxation and the underground economy", Journal of Public Economics, Volume 88, Issues 1-2, January 2004, Pages 395-418

[24] Hamermesh, Dan, "Labor Demand and the Structure of Adjustment Costs", American Economic Review, 79 (1989), 4.

[25] Heckman, James and Carmen Pages, Law and Employment: Lessons from Latin American and the Caribbean (Chicago: The University of Chicago Press for the NBER, 2003).

[26] Holmes, Thomas, "The Effect of State Policies on the Location of Manufacturing: Evidence from State Borders", Journal of Political Economy, CVI (1998), 667-705.

[27] Johnson, Simon, Daniel Kaufmann and Pablo Zoido-Lobaton, "Regulatory discretion and the unofficial economy", American Economic Review, LXXXVIII (1998), 387-392.

[28] Kugler, Adriana and Kugler, Maurice, "The Labor Market Effects of Payroll Taxes in a middle Income country: Evidence from Colombia". CEPR Discussion Paper No. 4046, 2003.

[29] Kumar, Krishna, Raghuram Rajan and Luigi Zingales, "What Determines Firm Size?", NBER wp. 7208 (1999).

[30] Lall, Somik, Richard Funderburg and Tito Yepes, "Location, Concentration, and Performance of Economic Activity in Brazil", World Bank working paper 3268 (2004).

[31] La Porta, Rafael, Florencio Lopez-De-Silanes, and Andrei Shleifer, "The Economic Consequences of Legal Origins", NBER Working paper \# 13608 (2007). 
[32] Lazear, Edward, "Job Security Provisions and Employment" Quarterly Journal of Economics, CV(1990), 699-726.

[33] Levitt, Steve, "Using Electoral Cicles in Police Hiring to Estimate the Effect of Police on Crime", American Economic Review, LXXXVII (1997), 270-290.

[34] Loayza, Norman, "The Economics of the Informal Sector: A Simple Model and Some Empirical Evidence from Latin America", Carnegie-Rochester Conference Series on Public Policy, XLV(1996), 129-62.

[35] Loayza, Norman, Ana Oviedo and Luis Serven, "Regulation and Macroeconomic Performance," World Bank Policy Research Working Paper No. 3469, 2004.

[36] Loayza, Norman, Ana Oviedo and Luis Serven, "The Impact of Regulation on Growth and Informality: Cross Country Evidence", World Bank Policy Working Paper No 3623, 2005.

[37] Maloney, William, "Informality Revisited", World Development, XXXII(2004), 1159-78.

[38] Micco, Alejandro, and Carmen Pagés, "The Economic Effects of Employment Protection: Evidence from International Industry-Level Data," Discussion Paper 2433, IZA, Bonn, Germany (2006).

[39] Naritomi, Joana, Rodrigo Soares and Juliano Assuncao, "Rent Seeking and the Unveiling of 'De Facto' Institutions: Development and Colonial Heritage within Brazil', working paper, PUC-Rio de Janeiro (2007).

[40] Neri, Marcelo C., "Decent work and the informal sector in Brazil". EPGE, Ensaios Economicos, 461 (2002).

[41] Nickell, Stephen, "Unemployment and Labor Market Rigidities: Europe versus North America", Journal of Economic Prespectives, XI(1997), 55-74.

[42] Nickell, Stephen and Richard Layard, "Labor Market Institutions and Economic Performance", in O. Ashenfelter and D. Card, eds., Handbook of Labor Economics (Amsterdam: North Holland, 2000).

[43] Oi, Walter, "Labor as a Quasi-fixed Factor", Journal of Political Economy, LXX(1962), 538-555.

[44] Polinsky, Mitchell and Shavell, Steven, "Corruption and optimal law enforcement", Journal of Public Economics, Volume 81, Issue 1, July 2001, Pages 1-24

[45] Rajan, Raghuram and Luigi Zingales, "Financial Dependence and Growth", American Economic Review, 88 (1998), 559-586.

[46] Safavian, Mehnaz, and Siddharth Sharma, "When do creditor rights work?," Journal of Comparative Economics, 35, 3: 484-508 (2007). 
[47] Scarpetta, Stefano and T. Tressel, "Boosting productivity via innovation and adoption of new technologies: any role for labor market institutions?" World Bank Discussion Paper, 2004.

[48] Schneider, Friedrich and Dominik H. Enste, "Shadow Economies: Size, Causes, and Consequences", Journal of Economic Literature, XXXVIII(2000), 77-114. 